\title{
Article
}

\section{Design Errors in Ship Design}

\section{David Andrews}

check for updates

Citation: Andrews, D. Design Errors in Ship Design. J. Mar. Sci. Eng. 2021, 9, 34. https://doi.org/10.3390/ jmse9010034

Received: 27 November 2020 Accepted: 22 December 2020 Published: 31 December 2020

Publisher's Note: MDPI stays neutral with regard to jurisdictional clai$\mathrm{ms}$ in published maps and institutional affiliations.

Copyright: (C) 2020 by the author. Licensee MDPI, Basel, Switzerland. This article is an open access article distributed under the terms and conditions of the Creative Commons Attribution (CC BY) license (https:// creativecommons.org/licenses/by/ $4.0 /)$.
Department of Mechanical Engineering, University College London, Torrington Place, London WC1E 7JE, UK; d.andrews@ucl.ac.uk

\begin{abstract}
There is a problem in coping with design errors in ship design. Ships are generally very large and often very complex. Yet, we rarely invest in full-scale prototypes so design errors are frequently revealed once ships are at sea and certain errors can be catastrophic, others lead to many ships having shortened useful lives. The paper starts by considering the nature of design errors and failures in large-scale engineering enterprises. This is followed by looking briefly at some lessons from maritime history concerning how design errors arise and can even lead to ships sinking. A specific well-documented case of calculation error in sizing a new ship design is reviewed and lessons drawn. The relevance of general approaches to avoiding engineering errors and ever-greater emphasis on risk mitigation procedures and applying safety regimes alongside ethical guidance is reviewed. The changing nature of ship design practice is discussed, with ship designers between the horns of the dilemma of ever greater ability provided by computer driven precision and the demands for their designs to be seen to perform effectively in an increasingly uncertain and complex world. Final thoughts consider the basis for judging what might be good or bad ship designs, how errors can be addressed, and the ultimate safety role of the naval architect as the overall designer of complex vessels.
\end{abstract}

Keywords: design of complex vessels; Hunt Class Escorts; haddon-cave report; design authority; safety case; duty holder; "good" and "bad designs for service vessels

\section{Introduction}

"Truth will sooner come out of error than from confusion" Francis Bacon, 1620, The New Organon [1]

"If it looks right, it probably is right, if it looks wrong, then check it out", Sir Rowland Baker, 1955 [2]

Designers of complex engineering products need to understand how and why design errors arise. Just as important is to realise errors will occur but also many can often be avoided and this can be seen to be a mark of good engineering practice. The demands on ships across the spectrum of employment from commercial shipping underpinning most of global trade to many disparate service vessels are getting ever more sophisticated and marine vehicles are growing in complexity. This applies not just to the technologies employed and the environment in which ships operate, but also the way in which ships are designed and the environment in which designers perform their increasingly sophisticated role throughout a ship's life.

Sometimes in the long history of ship design safety was not well understood by sailors and designers and the fact that lives are still regularly lost at sea is a sobering fact for those designing ships. The naval architect as the principal engineer involved in most ship designs should always be conscious that if they fail to design a safe ship and ensure the design can largely cope with the unexpected then ships can sink and lives lost. Having said that, the ship design process is also getting more complex [3] and better analytical tools do not reduce the designer's responsibility, they make it more important that safety issues are given prominence and design errors mitigated. 
The occurrence and prevention of design errors is part of the whole safety and risk issue. The Royal Academy of Engineering produced a series of guides on risk [4], which showed the scope of this. Thus the first guide addresses "Society's" perception of risk and identified that engineers need to go beyond their "traditional numerical approach" to acknowledge the importance of the "cultural construction of risk". The second guide is on "Common Methodologies" and emphasises how engineering risk should be built into the corporate risk management of any enterprise with a significant engineering component, while the third guide on "Humans in the Control Loop" states engineers need to be much better aware of human factors related issues, especially in operating and maintaining engineering products.

This more nuanced approach to risk was reinforced in a recent article on safety [5], which talks of Reason's "Swiss Cheese" model (i.e., layers of hazard prevention barriers, where each contains unintended "holes, which if they "line up" cause major failures). Interestingly, the article cautions overly focusing on avoiding serious accidents since this can lead to neglect of infrastructure maintenance and to increases in routine personnel injuries.

The eminent writer on engineering history and practice, Petroski highlights the importance of understanding design failure [6,7]. He has shown that after each revolution or paradigm shift (such as his favourite case study of the last 200 years of bridge design) engineering designers need to tread cautiously. Having mastered a new design approach, they often seem to begin to extend (too) boldly, forgetting the original underlying assumptions. This then seems to result in the next generation of engineering designers over reaching, often pressed by hubris, competitive pressures and (technically) ignorant "customers". Secondly, he pointedly comments on engineers' ever increasing reliance on computers. Petroski concludes engineering designers need to recognise that most codes have undetected errors, most users don't question the appropriateness of modelling and fancily presented results, and furthermore, readily produced masses of results can hide the indications of errors.

Brooks, author of the key text "The Mythical Man-Month" on software engineering, in Reference [8] considers the nature of engineering design in general, where he assigns a vital place to how to deal with the possibility of design failure, or design error using the current paper's term. Thus, Brooks says: study failure examples more carefully than successes; be wary as success stimulates confidence in your design technique, the design itself and oneself; think strategically about the object being designed and its assumptions about the environment it will be in and ask whether those assumptions will still be valid a decade hence and are you designing the right thing? The latter is seen to be a fundamental point at the start of any complex design process and for this, the author has coined the term requirement elucidation (see Reference [3] for a justification of this term).

The next section looks at several historic examples of ship failures from a design perspective, which is followed by a summary of a very well documented example of a clear calculation error in early stage ship design and why this arose. This pre-World War II example is contrasted with the author's experience when he was the most senior naval architect responsible for the safety acceptance of new naval surface ship designs for the Royal Navy. Section 4 looks at strategic approaches to safety and error avoidance, focusing on the particular investigation conducted by Sir Charles Haddon-Cave into the loss of RAF Nimrod XV230 over Afghanistan in 2006, which laid down, at least for UK military equipment, best practices for safety management [9]. The next section considers the rapid and fundamental changes underway in the practice of ship design and what this might mean for further sources of design error and potentially better design assurance. The concluding section considers whether a design can be assessed as a good or bad design and how that fits in with good practice to better avoid design errors. Yet, in the end, errors will occur when obtaining such complex systems and the naval architect remains best placed to minimise many of those most fundamental errors arising in ship design. 


\section{Lessons from History-Where Design Errors Sink Ships}

Can we draw lessons from history? As Petroski pointed out [7], engineering has progressed through failures, but is that so when the failure is due specifically to design error, and is a design error the same as ignorance or mismanagement? A series of wellknown ship disasters are briefly considered below to see if there are issues that could be seen as design errors that caused the vessels to sink or, in the last case, the near loss of the vessel.

\subsection{Mary Rose 1545}

In early ship design and building, the two were effectively synonymous and entirely craft based, so they were bound to be error prone given the lack of engineering understanding. This was especially so with a new technology, which in Henry VIII's new navy arose with canon and openable gun ports close to the waterline. The Mary Rose was a recently rebuilt ship, heavily top loaded, which heeled sufficiently to flood in through the gun ports left open. Was this design or operator error? Certainly any new technology (e.g., canons plus closeable gun ports) brings risks designers need to think through.

\subsection{Vasa 1628}

Another "pride of the fleet" capsized off Stockholm, in this case on her maiden voyage. It would seem that the original designer, a Dutchman, had been persuaded by the King, Gustav Adolphus, to fit more and more canons high in the superstructure and that a simple heel test alongside showed the ship to be unstable. Unfortunately that master shipwright had died and been succeeded by a Swede, who could not tell the King he couldn't have his battle winning features. So, is this an example of poor design or the wider error of the (knowledgeable) designer not telling the "owner" they can't have what they want? This would still seem a too common failure (or design error) as identified by Haddon-Cave (see Section 4.1).

\subsection{HMS Captain 1870}

In a period of rapid technological developments (like Mary Rose but more so) the leading maritime power, Britain, wished to have the new "super gun" and allowed its proponent, a Captain Coles, to "develop his own ideas (of a low freeboard vessel)" [10] and build the ship in a non-navy yard. This was agreed due to political pressure and done against the strong objections of the Chief Constructor of the Navy, Sir Edward Reed, who resigned "due to the lack of technical understanding shown by some of the (Admiralty) Board" [10] when the ship as built was grossly overweight. On its maiden voyage in the English Channel, it was lost with 473 lives and the massive public enquiry led to "the end of the amateur in (naval) ship design and the achievement by the professional naval architect of real authority" [10]. So, the design error here would seem to be designer ignorance but also government listening to amateurs, in the hope of a leap forward, rather than to the experts. (Perhaps, a cultural lesson that needs continually to be learnt?)

\subsection{RMS Titanic}

This story seems the too familiar one of "unsinkable hubris". However the technical issues of ship stability were by now established (thanks to Reed and his staff's work at the time of the loss of HMS Captain) and, to a large degree, the design was sensible. The captain's action of turning away from the iceberg led to such extensive flooding that was hard to predict and was catastrophic for so many. Was this design error? Not really, as any ship will sink if it loses sufficient buoyancy [11]. A major design error was the inadequate lifeboat provision, which SOLAS subsequently corrected for all passenger ships. The fact that this inherently stable ship took $2.5 \mathrm{~h}$ to finally plunge by the bow (not capsize) is often overlooked and is in stark contrast with the next example. 


\subsection{Ro-ro Ferry Estonia 1994}

The loss of Estonia with 850 lives was not the first European Ro-ro ferry loss but certainly the worst since this form of rapid automotive vehicle load on-load off configuration was introduced in the 1960s. That this was done knowing that low, ship length continuous spaces (i.e., without transverse watertight bulkheads breaking up the ro-ro car deck) if flooded, due to ship collisions or failure to close or secure the bow loading door, would cause a free surface effect, which would very rapidly heel the ship on to its side and then capsize the vessel. The $2.5 \mathrm{~h}$ of Titanic's survival is in stark contrast to $2.5 \mathrm{~min}$ for Estonia to heel over. That this did happen when it had been pointed out that this could be avoided by fitting compartments outboard of the car deck, as it had been in naval amphibious (dock) ships, seems unforgivable. Such watertight compartmentation can fully restore the ship's intact stability should the free surface effect on the car deck occur [12]. Was this a "design error" or a collective failure of government (UK Department of Transport in sinking of Herald of Free Enterprise and then the Scandinavian maritime agencies), the ferry owner/operator, and even the naval architecture profession, who argued (but perhaps not sufficiently to be heard in the corridors of power) for the sensible and relatively moderate outboard watertight compartmentation, which has now been incorporated by law?

\subsection{Launch of HMS Ocean 1991}

Designing a ship is not just doing the calculations to realise the eventual vessel, there are other activities necessary to get the ship to sea. Literally, one set of activities is those tasks to get it in the water and this can be risky if not done adequately [13]. Naval ships are normally built in shipyards familiar with such vessels and historically naval architects were trained to check such potentially risky events as dynamic launching down the building slip. HMS Ocean was a radical departure from naval design practice as a major warship in an attempt to get a much cheaper commercial ship based procurement. This meant past practice was ignored and the $\mathrm{UK} \mathrm{MoD}$ procurement approach to oversight in the shipyard was left to the prime contractor, who then left it to the commercial yard building the ship. Thus, the forward poppets were not cribbed, which is normal practice with fine naval hull forms [14] and on launch they flew off and the stem of the ship was severely damaged when it hit the concrete launch berth. Luckily, the speed of the launching and both poppets detaching one aft the other avoided a more catastrophic sideways toppling. The lack of experienced naval architects in the "hands off" project team could seem another example supporting Haddon-Cave's critique of obeying the formalised exercise of procedures in lieu of adequate technical scrutiny by the ship's owner, in this case HM Government (see Section 4.1). This example, which could have been much worse, reveals design errors are not confined to obvious elements of the design evolution.

So what can be concluded from these largely very historic disasters? In part, design errors arise not just from technical errors, such as is detailed in the next section, but also from the wider environment in which design takes place. This is because ship design is complex [3] and such design is not a closed and solely technical process, but often a sophisticated sociopolitical undertaking [15]. Furthermore, as the next section shows, obvious mistakes particularly arise when design organisations are under extreme pressure.

\section{Some Lessons from a Specific and Well-Documented Case-WWII HUNT Class Escorts}

\subsection{HUNT Class 1938}

This design was commenced in late 1938, a time of intense design activity, when the Royal Navy was belatedly and rapidly rearming for the imminently expected war with Hitler's Germany. One quick need was for a large (and cheap) class of "fast escorts" of some 1000 tons, $30 \mathrm{kts}$, with a "powerful anti-aircraft (AA) armament" and able to be rapidly produced. The design responsibility ultimately lay with Reed's successor of the day, the brilliant Sir Stanley Goodall, RCNC, as Director of Naval Construction and Principal 
Technical Advisor to the Admiralty Board, who approved every Royal Navy design himself and thus was driving the rebuilding of the Navy's fleet [10]. The history of this unusually well documented example of a design error in a specific calculation has been analysed by the well-respected former MoD Deputy Chief Naval Architect (DCNA) and eminent technical author, David K Brown. Brown summarised his un-published detailed 14 page analysis to provide input to the article on the HUNTS by English [16]. Below is a summary of Brown's detailed analysis and his concluding general remarks on design errors in ship design [17]:

Brown lists ten specific aspects in the history of the HUNT Class design error:

1. The Hunts had twice the gun armament of the earlier S Class sloops and this should have alerted the design team that the ships' stability might be an area of concern.

2. In Goodall's daily diary he expressed the view on the Hunt design team that he felt the team was "poor". This should have meant he would have supervised them better but he was overloaded with other more major programmes in making up for years of underfunding of both new ships and modernising an aged fleet.

3. As AA vessels they needed a long roll period which meant a low metacentric height (GM) but that would mean any error in calculating this low GM could result in insufficient transverse stability. Thus, even more care was required in calculating the ship's predicted vertical centre of gravity (KG).

4. As the design was worked up there were several indicators that there might be an error in calculating the necessary waterline beam (to provide a sufficient metacentric height), which were ignored, probably due to the rearmament pressures.

5. It would seem only the arithmetic was checked, rather than considering (with the above special issues) a wider view of "does it look right?" (Brown made an interesting side comment that such an attitude can be even more dangerous when computers are being relied upon: the well-known "Rubbish in: Rubbish out").

6. In applying a check using the design of a larger vessel, the team should have been aware this scaling down is known to be more difficult to do accurately than the opposite.

7. In early-stage design, a lot is based on tried and trusted "rules of thumb". These are often "invaluable" where there is lack of firm data but this can also be misleading, so requires experience, judgement and stringent questioning from the design team.

8. An excellent check was carried out using the much larger "J" Class Destroyers, however, only the weights were checked, not the vertical centroids (KGs) where the error lay.

9. The major error emerged when a gun turret was installed and the ship lolled. (Goodall had previously increased the design beam by 9 inches because it seemed insufficient.) The error was probably that, the KG for the Upper Deck steel weight $7 \mathrm{ft}$. was used, not the actual $17 \mathrm{ft}$. from the Keel to the Upper Deck. (Thus, a figure of $1200 \mathrm{ton} \mathrm{ft}$. was omitted and Brown calculated two thirds of this could have been due to that design error with the rest due to increased topweight (due to additional equipment) arising during the subsequent design development and construction.) Brown notes that there was a standard second "independent calculator" but that individual obviously copied the mistake, so failed to provide the assurance of an independent calculation. Brown's comment was "shoot the 2nd calculator"! The design had been approved by Goodall (with his 9 inch addition to beam), in signing off the Hunt Class Book of Calculations. The Book of Calculations for each new design was always based on the relevant details in the Assistant Constructors' (i.e., the calculators) Workbooks. These are all held in the National Maritime Museum, Greenwich once they have been declassified. These workbooks are no longer the basis of approving R.N. ship designs as nowadays contractors produce designs and use computer programs, such as spreadsheets for initial sizing, not formalised workbook-based calculations.

10. The response to the observed loll of the first ship when fitting out was to remove, from the design and build plans, several guns on those ships already well advanced. 
Then a redesigned Batch II class had their beam increased from the designed $28^{\prime} 3^{\prime \prime}$ (this was before Goodall's additional 9 inches) to $32^{\prime} 6^{\prime \prime}$, which enabled the original armament to then be installed-see comparison in Figure 1.

\section{THE HUNT CLASS}

\section{A Case Study in Design Error}

Dovid R. Brown, RCNC

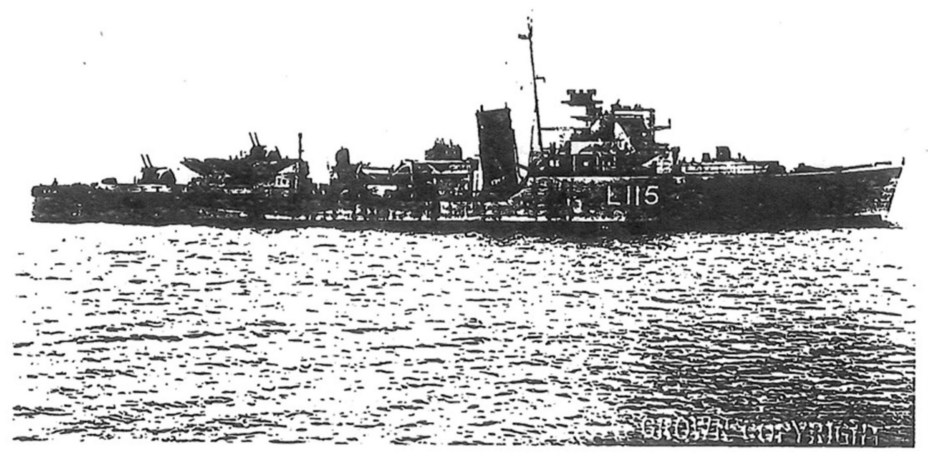

As they were designed with three twin 4 inch mounts and a four barrel pompom. This photo shows SLVERTON, a Batch II ship with beam increased to $32 \mathrm{ft} 6 \mathrm{in}$.

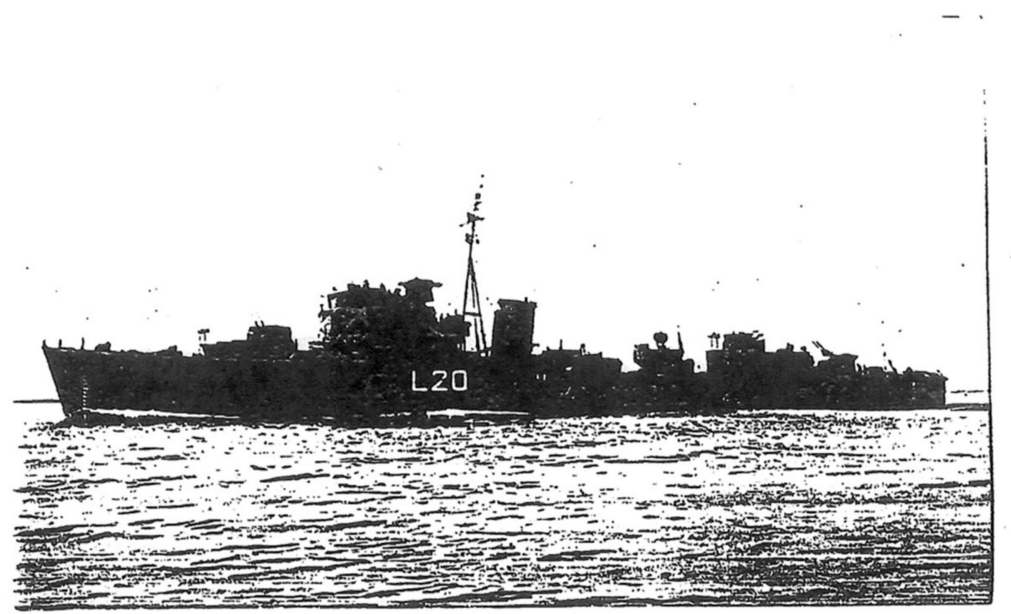

GARTH was a Batch I ship showing her as altered with only two 4 inch mounts, a cut down superstructure and bridge.

Figure 1. Comparison of 1938 HUNT Class Batch I and Batch II [17].

David Brown's three general conclusions from his investigation were [17]:

- Errors in any complex engineering design endeavour (even with computers) are inevitable. Senior and competent officers must check the work of the junior engineers doing the actual design calculations. Brown suggests trend curves should be used, if close comparators are not available, and if the new design is one standard deviation from expectation then the design organisation should institute a formal enquiry.

- In ship design the use of type ships is common (see Section 5.2 of Reference [3] for explanation of this term) but this is also risky with the danger of an inappropriate applicability. Even using several designs in trend curves can introduce risk due to data scatter (and further inapplicability). 
- If a design error is found, then there should be a formal enquiry, but this should not be witch hunt as then evidence, at best, gets "buried". (Interestingly, Brown (in 1987) exampled Boeing's aircraft practice as they "have a good procedure". This was obviously written before the recent 737 MAX debacle, which may destroy Boeing's engineering credibility: so much for "procedures".)

\subsection{Design Authority and Duty Holder}

By way of considering Brown's forensic analysis of the HUNT Class, it is worth outlining the aspect of design responsibility for both military/naval aircraft and vessels under the term design authority (DA). This was outlined in the interesting case of the current R.N. Daring Class Destroyers [18], which the current author questioned [19] as to whether DA could (as in this specific case) be genuinely placed (as it is regularly for military aircraft) with an individual in industry rather than with a competent individual in the government (warship) acquisition agency. Apart from a brief period at the end of the 20th Century, when naval DA was handed over during acquisition to the relevant industry prime contractor, as was done for at least two major vessel designs, all R.N. vessels, as in case of the 1938 Hunt Class when the DNC was effectively the Design Authority, have a specific Duty Holder at senior level. That individual signs off the design and retains the responsibility for design aspects of ship safety of all vessels built to that new design throughout the life of all R.N. vessels, while each Commanding Officer holds operational responsibility for their ship.

When he was Deputy Chief Naval Architect, Brown stated the nature of the personal verification by the Duty Holder, namely, "I have personally examined these calculations and I believe them to be correct." In his last post in the UK Ministry of Defence, as a Director Surface Ships, the author was the only naval architect on the Management Board of the Director General Surface Ships. The DGSS at that time had to sign off all new ships to complete their safety certification and as a naval weapons engineer said he would only sign once I, as the most senior naval architect on his staff, had assured him that the safety case was satisfactory. This safety case had been produced by industry and checked by the MoD Director of Naval Architecture, but the admiral nevertheless required my personal assurance before he signed. So who was finally professionally responsible?

Prior to 1960, all R.N. designs were always signed off by the most senior naval architect in government, who was the DNC. He did so approving the Book of Calculations for that design and this was where the calculators were named and their specific work, on which the $\mathrm{B}$ of $\mathrm{C}$ was based, referenced. Now with most direct design work on R.N. vessels being done by industry, it is still the Duty Holder in government that signs off the Safety Case, if not the whole design. However, that person may not be a naval architect, and so the "signee" is in a similar situation to the DGSS example above. In contrast, US Navy ship designs are still signed off by the most senior civilian naval architect who is the Technical Director Ship Design in the US Navy headquarters (NAVSEA Command). Yet, interestingly, it was the naval engineering admiral, as USN Chief Engineer, who was sacked for the design error on a carrier upgrade (rather than a new design) that had over compensated for the predicted stability degradation. This led to too stiff a roll motion, which prevented flying the latest aircraft off the vessel when it came out of refit.

\section{Strategic Safety and Oversight Issues}

In considering design errors it is sensible to look at the procedures that organisations responsible for complex engineering systems institute for safety assurance. Thus Safety Cases [20] along the lines mentioned in the previous section, are intended to give that assurance. However, it can be the situation that the adherence to management processes can lead to "box ticking" at managerial level and split bureaucratic organisations blurring what should be clear lines of responsibility. Design risk actually originates at the individual design engineer's level, as they make myriad design decisions [21], which their senior engineers need to check as part of design verification and subsequent safety assurance. 
Despite this engineers can make mistakes, often due to cost and or schedule pressures, such as in the 1938 Hunt Class case. Worse, design engineers do flag up high risks, such as the NASA Challenger booster rockets "O" rings, and then are ignored, clearly revealing systemic organisation failure [22] as does the next example, despite a plethora of "safety procedures".

\subsection{Haddon-Cave's Report on 2006 Nimrod Explosion}

Sir Charles Haddon-Cave, Q carried out a review, producing a very comprehensive report, following RAF Nimrod XV230's catastrophic mid-air fire induced explosion in 2006. This was the biggest single loss of UK personnel in the Afghanistan campaign. The direct cause was leaking fuel ignited by a hot cross feed pipe but Haddon-Cave [9] was clear the causes were "organisational and managerial". He quotes Schumacher:

"Any intelligent fool can make things bigger, more complex, and more violent. It takes a touch of genius-and a lot of courage-to move in the opposite direction."

Haddon-Cave's analysis concluded that there had been an accumulative set of causes: poor design and then poor modification; a history of fuel leaks with these aircraft; increased operational tempo combined with the problem of maintaining ageing aircraft; then there were the "distractions" of major organisational change (a typical bureaucratic euphemism for cuts); and finally totally inappropriate sourcing out of the Nimrod Safety Case in 2004/5, leading to the ultimate failure of safety ownership.

Haddon-Cave drew several extensive messages from his review, which in summary consisted of: seven themes, including the complexity of the organisation, reliance on "paper based" safety, and "the triumph of generalists over specialists" (where he especially criticised non-technical "consultants" with MBAs); seven lessons, from which the highlights are the "comfort blankets of complexity, compliance and consensus". He even said such organisations should encourage staff to be awkward. If the Ministry of Defence outsourced much of its technical effort (including safety related work), then it must still remain an intelligent customer to understand what has been done by its contractors; finally, the safety case (for such complex systems, whether on acquisition or in the continual upgrading through life) must be an aid to ownership not an end in itself.

Haddon-Cave's summary was quite pointed:

- $\quad$ Return to a belief in core values and technical skills.

- Tighten lines of responsibility and identify the duty holder.

- Roll back procedures and simplify the process.

\subsection{Engineer's Ethics and the Golden Rule for Engineers}

We are discussing engineering design errors and thus entirely apposite are the issues of professional competence and ethics, already mentioned in the introductory remarks. Every Corporate member of the naval architectural profession is obliged to meet the following: "shall at all times so order his/her conduct as to uphold the dignity and reputation of his/her profession: to safeguard the public interest in matters of safety and health and otherwise." [23] Furthermore: "They shall exercise his/her professional skill and judgment to the best of his/her ability and discharge his/her professional responsibilities with integrity" [23].

The issue of ethics for naval architects was addressed in a landmark paper by Rawson, who has already been referenced [12] with respect to the Estonia example at Section 2.5. The paper is entitled "Ethics and Fashion in Design" [24] and draws upon his experiences with both ro-ro vessels (as chair of the RINA Safety Committee) and the short-fat ship controversy (see Reference [25] for the current author's summary). Among the extensive published discussion to Rawson's 1989 paper one was by an eminent naval architect that highlights the conflict between a commercial customer and the ship designer [26]. It concerned producing a damage stability statement, where Heather found a case that flooding one particular compartment would sink the ship. The customer's response was 
"In that case, find a condition in which it doesn't sink and prepare me a stability statement based on that" - that is not an example of design error, but a demand verging on the criminal, where ignorance by the customer should be no defence and asking the designer to do such an activity clearly infringes professional ethics.

The golden rule for all engineers has to be:

If you are working outside your area of knowledge and there is a safety issue:

- $\quad$ Don't sign off the safety case.

- $\quad$ Find someone who can do so.

The ultimate mark of a professional engineer is to know your own limitations.

\section{The Changing Nature of Ship Design}

With the immense changes in ship design since the advent of CAD the issue of design errors has changed in many respects from that of the 1938 Hunt Class debacle. Thus, the design problem has become more complicated, however it could be argued that all three of Brown's issues, at the end of Section 3.1, are still fundamental, but there are just many more issues and constraints today to add to the complexity [3].

Why is this so? Certainly for naval vessels, the demand is for better ships and, for all seagoing ships, more stringent standards of not just safety but also performance (see Section 6.3). This has come about because there are better tools to do design better and even to understand a given design "better" in all its sophistication. Thus we can analyse the behaviour of ships with FEM and CFD, we can make more responsive and better integrated models, and we have AI and Data Driven Design to further improve our practice [27]. Many see optimisation and systems engineering as ways ahead in engineering design, but they can also introduce design errors and risks in being misapplied in designing complex vessels [28,29].

In many respects the problem has become worse for the actual naval architects doing ship design. They are more than ever reliant on detailed specialists, so can either party see "the wood for the trees" [30]? This is not just with regard to traditional technologies but also given ship designers produce mobile artificial environments in which people don't just work but also in which they live, there is growing pressure to also better design the ship for human factors aspects at sea $[31,32]$.

The approach to early-stage ship design is very often imbued with a lack of recognition of the true nature of this design phase to deal with the "wicked problem" of what is sensibly achievable in the rush to get into "real" design [3]. Many more options should be properly explored (i.e., requirement elucidation) and the importance of style selection (see Table 1) recognised. Also there are different levels of design required depending on design novelty, each needing a different approach (see Table 3 in Reference [3]). There are today ever more constraints (see Table 2 in Reference [3]) and a design environment subject to incessant improvement/reorganisation, both of which risk the design team losing sight of key issues and a common belief that ship design producing organisations can manage risk by process rather than the primary focus being achieving good design (a view soundly demolished by Haddon-Cave). Yet, it would seem also that the ship designer has less than their traditional authority with more managers and general systems engineers "managing ship projects" [29]. The demands of ship safety, and who really is signing off a ship design, mean that there is a danger that the naval architect is reduced to just being the "hull engineer" [33]. 
Table 1. Comparison of style topics relevant to a naval combatant (all) and a commercial service vessel (OPV) (underlined).

\begin{tabular}{|c|c|c|c|c|c|}
\hline Stealth & Protection & Human Factors & Sustainability & Margins & Design Style \\
\hline $\begin{array}{l}\text { Acoustic } \\
\text { signature }\end{array}$ & Collision & Accommodation & $\underline{\text { Mission duration }}$ & Space & $\underline{\text { Robustness }}$ \\
\hline $\begin{array}{l}\text { Radar cross } \\
\text { section }\end{array}$ & $\underline{\text { Fire }}$ & Access & Watches & Weight & $\underline{\text { Commercial }}$ \\
\hline Infra-red & $\begin{array}{c}\text { Above water } \\
\text { weapon effect }\end{array}$ & $\underline{\text { Maintenance levels }}$ & $\underline{\text { Stores }}$ & $\begin{array}{c}\text { Vertical centre of } \\
\text { gravity }\end{array}$ & $\underline{\text { Modularity }}$ \\
\hline Magnetic & $\begin{array}{c}\text { Underwater } \\
\text { weapon effect }\end{array}$ & Operation automation & Maintenance cycles & $\underline{\text { Power }}$ & $\frac{\text { Operational }}{\text { serviceability }}$ \\
\hline \multirow[t]{4}{*}{ Visual } & $\begin{array}{c}\text { NBC } \\
\text { contamination }\end{array}$ & \multirow[t]{4}{*}{$\underline{\text { Ergonomics }}$} & Refit philosophy & Services & Producibility \\
\hline & Shock & & Upkeep by exchange & $\begin{array}{c}\text { Design point } \\
\text { (growth) }\end{array}$ & Adaptability \\
\hline & Corrosion & & & $\begin{array}{c}\text { Board Margin } \\
\text { (future upgrades) }\end{array}$ & \\
\hline & Damage control & & & & \\
\hline
\end{tabular}

\section{Final Thoughts}

\subsection{Good and Bad Design}

While it could be argued a lack of serious design errors define a "good ship design", this is a little simplistic. The novelist C S Forester [34] captures the essence of the issue in what a ship designer must/can't satisfy:

"He ends, of course, by satisfying neither the Commander who is responsible for the men's living conditions, nor the Gunnery Officer who is responsible for the guns, but that is the natural fate of the designers of ships-the speed enthusiasts, the gunnery experts and the advocates of armour protection, the men who have to keep the ships at sea and the men who have to handle them in action all combine to curse the designer.

Then comes the day of battle and the mass of compromises, which is a ship of war, encounters another ship of war, which is a mass of different compromises, and then, ten to one, the fighting men on the winning side will take all the credit to themselves and the losers—such of them that survive-will blame the designer all over again."

The naval ship author Preston, in considering bad ship designs, states: "There are many more bad staff requirements than there are bad ship designs" [35]. This might seem to get the ship designer off the hook but only if the designer's primary task is not seen to be that of elucidating the sensible mix of requirements together with the staff/owner, and hence pursue the author's term requirement elucidation [3]. While approaches, like epoch era applied to multirole offshore support vessel design [36] and Pareto Front to naval vessels $[37,38]$, try to tackle assessing multiple and diverse performance measures against some measure of cost, at best provide insights rather than absolute preferences. Two contrasting approaches to the issue of what is a "good ship design" are presented in the next sub-sections.

\subsection{Analysis of WWII British Navy Designs}

Brown [39] ends his analysis of R.N. ships from 1923 to 1945 with a chapter entitled "What is a good design?" Having reviewed the fleet's technical performance in WWII (a fleet largely designed under Sir Stanley Goodall), Brown's sub-headings for his assessment are:

- Foretelling the future: on the difficulties of getting a new ship design "right" (see Reference [3] on the 'wicked problem" and requirements elucidation); 
- Quality versus quantity: always a balance, Brown concluded British designs performed well in WWII, in that they were reliable (i.e., didn't break down, didn't (readily) break in half or capsize) but could have had better availability. In this latter regard they were better than most other navies, with the exception of the US Navy;

- A summary of specific problems: this covered the performance of machinery, weapons, structure, speed, habitability and seakeeping, concluding most other navies were worse (again the USN designs, aside from seakeeping, seemed superior);

- Good design (he lists key designs-concluding they were generally good but most could have been better);

- Fleet balance: probably the best that was achievable within the UK's marine industries capability to deliver.

Brown concluded the best design according to "some naval architects (is the design) that meets the (formal) requirement at a reasonable price" but he disputes that as being far too narrow a definition. He proposed a better definition lay in that by the 1842 committee on naval ship design which ends: "to endeavour to produce the best effects with given means", which broadens the basis but leaves the issue somewhat qualitative?

Two more recent British naval examples of relevance to judging "a good design" are the Type 22 Frigates and the Swiftsure nuclear submarine class, both of which were seen by senior naval officers, when they came into service in the height of the Cold War, as being "over designed". However, both classes were found to be highly and readily adaptable to major new operational demands. Thus, that frigate class was easily extended into two further batches, due to it bucking the obsession with too small and hence tight designs from being a generous design. The Swiftsures were built with what might have seemed excessive ballast margins [40] but enabled the "Improved Swiftsure Class" (the successful Trafalgar Class SSNs) to be seamlessly developed from them - no small feat in submarine design and procurement practice [40].

\subsection{A Service Vessel Approach}

Ulstein and Brett [41], the Chairman and Deputy Managing Director respectively of the highly innovative Ulstein shipbuilders, produced a key paper entitled "What is a better ship? It all depends", which could be said to encapsulate the problem. The paper describes a comprehensive approach adopted by Ulstein for their latest designs of sophisticated offshore support vessels (OSV). These are complex multi-role service vessels, comparable in many respects to naval combatants with a similar "wicked problem" [3]. They argue there are three perspectives on assessing a ship's performance:

a. Design for efficiency, i.e., technical, operational, commercial;

b. Design for effectiveness, i.e., safer, smarter, greener;

c. Design for efficacy, i.e., flexibility, robustness, agility.

Although some words are different this is not unlike Andrews emphasis on selecting the "Style" of a new design option (see Table 1 comparing a combatant and an OSV). Their paper goes on to outline (for 13 design options) a "multi-criteria Benchmarking process" for the aspects (a) and (b) above. They go on to show " a typical structure to handle rule and no-rule based decision making to get the best ship" when "intuition is not sufficient", though they acknowledge that the latter is often used. So they argue against the "more traditional ship design approach" and in favour of models that include relevant and broader perspectives, such as those above. Thus, for complex vessels, a more sophisticated approach to "good design" is clearly required.

\subsection{Accepting That Errors Will Always Occur}

The really big design decisions are made early in the design, hence this is the most important phase [3], yet it remains the case that the devil is in the detail. The latter echoes Ferguson's vision of the myriad of decisions made by any design engineer [21]. Furthermore, this remains the situation right to the end of the ship's life and owners of ships, 
commercial or government, do introduce errors that emerge through life, often by ignoring material degradation or making changes that exceed the original design assumptions.

But it remains the case that only the naval architect can be the actual ship designer, as they understand how to synthesize a new design, even if they do so by selecting a type ship to "copy" they are still making a design choice-see Section 5 of Reference [3]. Furthermore, everyone's problems, as they impact on design balance and coherence, are thus also the naval architect's problem as they have the sole overall design insight and must maintain a balanced and coherent ship design. Finally, only the naval architect can truly sign off the design, both from an overall basis and regarding most of its fundamental aspects of ship safety. Thus some simple final remarks:

- The naval architect's errors sink ships.

- It takes a computer to really screw up.

- Always be on guard, so don't trust anyone.

- Always believe there are further errors to be found.

- Don't go beyond your own competence and experience.

- Check, check and check again.

Funding: This work received no direct external funding.

Institutional Review Board Statement: Not applicable.

Informed Consent Statement: Not applicable.

Data Availability Statement: Not applicable.

Conflicts of Interest: The authors declare no conflict of interest.

\section{References}

1. Bacon, F. The New Organon, 1620 ed.; Lisa Jardine and Michael Silverthorne: Cambridge, UK, 2000.

2. Baker, R. How to Build a Ship; Royal Canadian Navy Publication: Ottawa, ON, Canada, 1956.

3. Andrews, D. The sophistication of early stage design for complex vessels. Int. J. Mar. Eng. 2018, 160, 1-54.

4. Turnbull, J. An Introduction to Three Reports on Risk Engineering; Royal Academy of Engineering: London, UK, 2005.

5. Johnson, J. Culture is still key to safety. Professional Eng. 2020, 5, 49.

6. Petroski, H. To Engineer is Human-The Role of Failure in Successful Design; St Martin's Press: New York, NY, USA, 1985.

7. Petroski, H. Success through Failure-the Paradox of Design; Princeton UP: Princeton, NJ, USA, 2006.

8. Brooks, F.P. The Design of Design-Essays from a Computer Scientist; Pearson Education: Boston, MA, USA, 2010.

9. Haddon-Cave, C. The Loss of RAF Nimrod XV230; Final Report; UK Sec of State for Defence: London, UK, 28 October 2009.

10. Brown, D.K. A Century of Naval Construction; Conway Maritime Press: London, UK, 1983.

11. Hackett, C.; Bedford, J. The sinking of S.S. Titanic-Investigated by modern techniques. TRINA 1996, 138.

12. Rawson, K. Ever the Apprentice; The Memoir Club: Stanhope, UK, 2006.

13. Rawson, K.; Tupper, E. Basic Ship Theory, 2nd ed.; Longman Group: London, UK, 1976.

14. Newton, R.N. Practical Construction of Warships; Longmans: London, UK, 1970.

15. Andrews, D. The conflict between ship design and procurement policies. In Proceedings of the RINA Warships Conference, London, UK, 11-12 September 2018.

16. English, J. The Hunts; World Ship Society: Kendal, UK, 1987.

17. Brown, D.K. The Hunt Class-A Case Study in Design Error. Personal communication, 15 October 1992.

18. Gates, P.J. Design authority for the Daring Class destroyers. TransRINA 2005, 147. [CrossRef]

19. Andrews, D. Discussion to Gates, P. J. Des. Auth. Daring Cl. Destroyers TransRINA 2006, 148.

20. Andrews, D. Recent developments in the safety regime for naval ship design. Qual. Reliab. Eng. Int. 2006, 22, 21-30. [CrossRef]

21. Ferguson, E.S. Engineering and the Mind's Eye; M.I.T. Press: Cambridge, MA, USA, 1992.

22. Feynman, R. Surely, you're Joking, Mr Feynman; Norton \& Company: New York, NY, USA, 1985.

23. RINA Code of Ethics. Available online: www.rina.org (accessed on 17 November 2020).

24. Rawson, K.; Ethics and fashion in design. TransRINA 1989. Available online: https://trid.trb.org/view/399862 (accessed on 27 October 2020).

25. Andrews, D. Andrews, D. A view from bath, a naval constructor's perspective. In Dreadnought to Daring; Hore, P., Ed.; Seaforth Publishing: Barnsley, UK, 2013; Chapter 23.

26. Heather, R. Discussion to Rawson, K. Ethics and fashion in design. TransRINA 1989, 129.

27. Gaspar, H. Data driven methods to handle complexity and to enable sophistication during ship design, contribution to Andrews D.; The sophistication of early stage design for complex vessels. Int. J. Mar. Eng. 2018, 160, 59-66.

28. Rydill, L. No, the future of Corps is not in Systems Engineering. RCNC J. 1966. 
29. Andrews, D. Ship project managers need to be systems architects not systems engineers. In Proceedings of the RINA Conference on Maritime Project Management, London, UK, 24-25 February 2016.

30. Noblesse, F. On the Importance of Being Earnestly Practical. GCMS'10, Ottawa, Ontario, July 2009. Available online: https: / / dl.acm.org/doi/abs/10.5555/2020619.2020631 (accessed on 27 October 2020).

31. Nautical Institute. Improving Ship Operational Design, 2nd ed.; The Nautical Institute: London, UK, 2015.

32. Andrews, D. Does the future ship designer need to be a human factors expert? In Proceedings of the COMPIT 2018, Pavone, Italy, 14-16 May 2018.

33. Andrews, D. Is a naval architect an atypical designer-or just a hull engineer? In Proceedings of the 13th International Marine Design Conference (IMDC 2018), Helsinki, Finland, 10-14 June 2018.

34. Forester, C.S. The Ship; Michael Joseph: London, UK, 1943.

35. Preston, A. The World's Worst Warships; Conway Maritime Press: London, UK, 2002.

36. Gaspar, H. Handling Aspects of Complexity in Conceptual Ship Design. Ph.D. Thesis, NTNU, Trondheim, Norway, 2013.

37. Burger, D.; Horner, D. The use of Paramarine and modeFRONTIER for ship design space exploration. In Proceedings of the 10th International Conference on Computer and IT Applications in the Maritime Industries, COMPIT 2011, Berlin, Germany, 2-4 May 2011.

38. Purton, I. Concept Exploration for a Novel Submarine Concept Using Innovative Computer-Based Research Approaches and Tools. Ph.D. Thesis, UCL, London, UK, 2016.

39. Brown, D.K. Nelson to Vanguard-Warship Design and Development 1923-1945; Seaforth Publishing: Barnsley, UK, 2000.

40. Andrews, D. Submarine design is not ship design. In Proceedings of the Warship 2017: Naval Submarines and UUVs, RINA, Bath, UK, 14-15 June 2017.

41. Ulstein, T.; Brett, P.O. What is a better ship?-It all depends. In Proceedings of the IMDC 2015, Tokyo, Japan, 3-5 June 2015. 